\title{
Izazovi izgradnje građanskog identiteta u Crnoj Gori: postreferendumske podjele i sporovi političkih partija
}

DOI: $10.11567 /$ met.31.1.1 UDK: 327.39(497.16)"2006/2014"

329(497.16)"2006/2014"

321.01

Izvorni znanstveni rad

Primljeno: 16. 06. 2014. Prihvaćeno: 11. 03. 2015.

\section{Danijela Vuković-Ćalasan}

Fakultet političkih nauka, Univerzitet Crne Gore, Podgorica danijelacalasan@gmail.com

\section{Mehmed Đečević}

Fakultet političkih nauka, Univerzitet Crne Gore, Podgorica medodjj@yahoo.com

\section{REZIME}

Postkomunistička tranziciona društva suočavaju se sa potrebom oblikovanja novih političkih identiteta u procesu izgradnje države i nacije i to u složenim unutrašnjim okolnostima. S obzirom da je proces izgradnje političkog identiteta nacionalno-državne zajednice jedan od najznačajnijih za njen opstanak i funkcionisanje, postavlja se pitanje: kakvog je oblika faktički politički identitet postreferendumske Crne Gore, naročito u dihotomiji građansko/nacionalno. Na temelju jedne od definicija građanskog političkog identiteta, naglašava se ustavno određenje Crne Gore kao građanske države. Istovremeno, uvažavajući veliki značaj koji u procesu oblikovanja Crne Gore kao građanske nacionalne zajednice imaju političke partije, sagledavaju se različite pozicije koje ove partije zauzimaju u navedenom procesu. Identitetske pozicije partija su predstavljene $u$ odnosu na dvije problemske ose: ustavno-pravnu i identitetsku u užem smislu. Ukazuje se da su u postreferendumskom periodu, u odnosu na identitetska pitanja, političke partije grupisane gotovo identično kao što $\mathrm{su}, \mathrm{u}$ predreferendumskom periodu, bile grupisane oko pitanja državno-pravnog statusa, te se u zaključku konstatuje blokovska podijeljenost u Crnoj Gori povodom identitetske problematike, kao i male mogućnosti da se identitetske polemike u skorijoj budućnost riješe konsenzusom.

KLJUČNE RIJEČI: građanski identitet, Crna Gora, političke partije, politički identitet 


\section{UVODNA RAZMATRANJA}

Nasljeđe autoritarnog poretka čini proces izgradnje i utemeljenja nacija i država u postkomunističkim tranzicionim društvima na Balkanu vrlo složenim. Problematika konsolidacije zajedničkih političkih identiteta na nivou političkih zajednica važna je i aktuelna, naročito ukoliko se radi o zajednicama sa izraženim etnokulturnim pluralizmom. Nacionalno i etničko ne gube na značaju i istrajnosti, suprotno očekivanjima različitih oblika modernizacijskih teorija a tendencija politizacije etnokultnih posebnosti, karakteristična za drugu polovinu XX vijeka, dodatno doprinosi njenoj aktuelizaciji. Za potrebe ovog rada polazimo od sljedećeg određenja pojma politički identitet: U pitanju je identitet koji podrazumijeva identifikaciju političkog tijela kojem pripadamo kao i normativno definisanje pravila igre čije usvajanje jeste sastavni dio političke zajednice ${ }^{1}$ (Cerutti, 2006: 33). Identitet moderne političke zajednice predstavlja spoj tzv. normationog i društveno-psihološkog identiteta (Cerutti, 2006: 34). U navedenoj definiciji politički identitet se izjednačava sa nacionalno-državnim identitetom, potencira se njegova građanska komponenta ali i svi oni elementi koji razvijaju osjećaj solidarnosti i čine da, sebe i jedni druge, prepoznajemo kao članove iste političke zajednice. ${ }^{2}$ Misli se prvenstveno na zajednička istorijska sjećanja, osjećaj kolektvne sudbine, prisustvo mita i simboličku dimenziju identiteta. Zahvaljujući činjenici da je ovakav identitet institucionalizovan, nacionalne države (p)ostaju dominantna forma političkog zajedništva. Sve, pa i one države koje se približavaju idealnom modelu građanskog nacionalnog identiteta (i koje karakteriše veći stepen inkluzivnosti i oslanjanja na političko-pravnu komponentu, prije nego na etnokulturnu), nastoje da

Politički identiteti mogu biti definisani i kao različiti oblici identiteta koji u određenom kontekstu postaju politički relevantni (u političkoj sferi nosioci različitih društvenih identiteta bore se za promjenu ili održavanje postojećih modela raspodjele moći). U tom značenju politički identitet se odnosi na identitet kolektivnih aktera u političkoj sferi. U skladu sa tim, Ilija Vujačić naglašava potrebu razlikovanja užeg i šireg značenja ovog pojma. Uže značenje vezuje se za opisivanje ideološko-političke privrženosti pojedinaca, zatim grupno-političke profilisanosti (identitet političkih partija, na primjer) kao i u ideološko političkom smislu kao, recimo, liberalni ili konzervativni identitet. Śre značenje, pak, odnosi se na veće kulturno-istorijske i političke strukture i poretke. U tom smislu, politički identitet može biti upotrijebljen u značenju nacionalno-državnog, regionalnog (identitet Balkana) i nadnacionalnog identiteta (poput identiteta EU) (Vujačić, 2012: 8). U širem smislu „politički identitet je samo uređenje (konstitucija) političke zajednice“ (Vujačić, 2012: 9). O političkom identitetu više i u: Knežević, 2012: 321-332. Ova problematika detaljnije je razmatrana i u članku „Politički identitet u multikulturalnim državama, s osvrtom na Crnu Goru“ (Vuković-Ćalasan, 2013).

2 Cerutti (2006: 50) upotrebljava sljedeće formulacije: „državno-nacionalni identitet“ odnosno „nacionalni politički identitet“. 
obezbijede integraciju etnokulturnih zajednica u zajedničku „socijetalnu kulturu“, jezičkom i institucionalnom kohezijom. ${ }^{3}$ Liberalno-demokratska država upravlja etnokulturnim razlikama, promoviše i jača zajednički politički identitet i određenu kulturu politikom širenja službenog jezika i zajedničkih institucija. To je dio procesa "građenja nacije“ (nation building) koji uključuje promovisanje nacionalnog u različitim dimenzijama (Kimlika, 2009: 382).

Neophodnost očuvanja kohezije društvene zajednice i njene stabilnosti, dobija dodatno na važnosti u uslovima izraženog etnokulturnog diverziteta savremenih društava. Osjećanje solidarnosti i zajedničke pripadnosti države obezbjeđuju homogenizacijom na principu nacionalnosti. Isključivo politička načela (liberalno-demokratske vrijednosti i načela pravde) u postojećim okolnostima, nedovoljna su za ostvarivanje neophodnog društvenog jedinstva koje mora biti utemeljeno na osjećanju solidarnosti: „Građani moraju osjećati da pripadaju istoj zajednici (...) Ukratko, društveno jedinstvo zahtijeva da se građani identifikuju jedni s drugima i da na svoje sugrađane gledaju kao na neke od „nas“. Ovaj osjećaj zajedničke pripadnosti i zajedničkog identiteta pomaže održavanju odnosa povjerenja i solidarnosti koji su potrebni da građani prihvate rezultate demokratskog odlučivanja (čak i onda kad su u manjini u donošenju određene odluke) i obaveze liberalne pravde“ (Kimlika, 2009: 290, 291). Država obezbjeđuje ovaj neophodni izvor političkog legitimiteta i solidarnosti u pomenutom procesu "građenja nacije“ korišćenjem sredstava poput sistema obrazovanja, nacionalnih medija, nacionalnog jezika, nacionalnih simbola itd. Navedeni proces legitimisan je i drugim pozitivnim efektima poput demokratizacije društva, budući da građanima obezbjeđuje mogućnost učešća u demokratskim procesima odlučivanja nezavisno od njihove etnokulturne pripadnosti (Kimlika, 2009: 87).

\section{GRAĐANSKI IDENTITET}

U građanskom modelu nacije tj. građanske države, građanska komponenta $\mathrm{u}$ strukturi političkog identiteta dominantna je u odnosu na etničku komponentu. Pomenuti model često se označava i kao „demokratska nacija“ („građanska nacija“). ${ }^{4}$ Crna Gora je ustavno definisana kao građanska

Socijetalnu kulturu Kimlika definiše kao „teritorijalno koncentrisanu kulturu, usredsređenu na zajednički jezik koji se koristi u širokom nizu socijetalnih institucija, i u javnom i u privatnom životu (škole, mediji, zakon, ekonomija, vlada itd.)" (Kimlika, 2004: 119).

4 O građanskom modelu nacionalnog identiteta i njegovom razlikovanju od etničkog oblika nacionalnosti pisali su brojni autori. Pregledno i jasno najvažnije razlike izdvojio je 
država, što upućuje na primat principa građanstva u odnosu na princip nacionaliteta. Međutim, mišljenja smo da je koncept građanske države kao postnacionalne prilično teško ostvariv u praksi, posebno za države koje se nalaze u područjima u kojima je tradicionalno dominiralo etnonacionalno. U praksi, država postoji kao nacionalna a ne postnacionalna i onda kada normativno rješenje upućuje na građanski koncept. Politički, nacionalnodržavni identitet koji bi bio u potpunosti ispražnjen od kulturno-etničkog sadržaja i sveden na pravno-političku komponentu, još uvijek nije u domenu realnosti. Kulturno-etnički elementi u praksi ne iščezavaju, izuzev u idealno-tipskom, teorijskom smislu. ${ }^{5}$

To nije ni neophodno ukoliko se imaju u vidu složena priroda i višedimenzionalnost građanskog nacionalnog identiteta. Naime, u ovom modelu nacionalnog identiteta građanstvo, kao ključna njegova komponenta, "pacifikuje“ kulturno-etničko kao potencijalno isključivo. Treba imati u vidu da građanstvo nije postojalo prije nacije nego tek $u$ okviru nje i daje joj politički izgled (Marković, 2010: 86). Dakle, na nivou nacionalno-državnog naglašavamo potrebu jačanja građanske solidarnosti u odnosu na solidarnost zasnovanu na pripadnosti nacionalnoj zajednici kao prvenstveno (etno) kulturnoj. Pri tom, politički identitet, u svojoj etnokulturnoj komponenti, ne smije biti sveden na pojedinačni etnički da bi bio sposoban za inkluzivnost (Vuković-Ćalasan, 2013: 81). To važi i za crnogorski politički identitet: „Jedinstveni crnogorski identitet zavisi od stepena prihvatanja kulturnog pluraliteta kao osnovne vrijednosti crnogorskog kulturnog prostora" (Spaić, 2010: 54). Nerealno je u složenim tranzicijskim procesima očekivati zaokret ka koncepciji „ustavnog patriotizma“ i utemeljenje političke zajednice isključivo na načelima i procedurama demokratije (Vrcan, 2006: 145; Kecmanović, 2006: 159). Insistiranje isključivo na građanskom principu ili pak isključivo na etničkom kriterijumu vodilo bi u egocentrični individualizam ili u autoritarni kolektivizam (Marković, 2010: 112).

Politički identitet dinamičan je po svojoj prirodi i nalazi se u stalnom procesu makar i minimalnog redefinisanja. Nepromjenjivost sadržaja, na čemu često insistiraju etnonacionalisti, zapravo nikada ne može biti njegova

Slobodan Divjak (Divjak, 2006: 97-110). Više i u: Divjak, 2002: 291-297; Smit, 1998: 22-30; Golubović, 1999: 74; Dženkins, 2001: 249-251; Brubaker, 1996: 168-174.

5 Brojni autori bavili su se ovim pitanjem. Kimlika naglašava da građanska država ne može postojati bez kulturno-etničke komponente i svedena isključivo na pravno-politička načela. Potreban stepen kohezije u multikulturnom društvu i zajednički politički identitet koji treba da obezbijedi osjećaj pripadnosti, ne mogu biti rezultat isključivo saglasnosti i prihvatanja pomenutih načela (Kimlika, 2004: 41, 71-73). George Schöpflin naglašava da su politička (civic) i kulturna (ethnic) dimenzija nacionalnog neodvojive i da, zavisno od tipa nacionalnog identiteta, dominira jedna ili druga (Kupchan, 1995: 38-39). 
karakteristika. To važi i za crnogorski nacionalno-državni, politički identitet. Sadržaj koji je imao u različitim istorijskim periodima, bio je rezultat složenih društveno-političkih okolnosti. Na početku stvaranja moderne crnogorske države, krajem XIX i početkom XX vijeka, poseban izazov u promovisanju zajedničkog političkog, nacionalno-državnog identiteta bilo je prevazilaženje, odnosno nadilaženje, plemenskih i lokalnih lojalnosti jačanjem osjećaja privrženosti na nacionalnom nivou. Konflikti lojalnosti na nivou plemena, ali i na nivou različitih grupa unutar plemenskih zajednica $u$ ovom periodu, učinili su proces nacionalne homogenizacije sporim i komplikovanim. Izražena plemenska lojalnost i identifikacija sa regionalnim i lokalnim identitetima (poput nahija), prisutna je u određenoj mjeri i u savremenom crnogorskom društvu, primjećuje Srđa Pavlović (2003: 88). ${ }^{6}$ Pružajući kratak i vrlo koristan pregled podjela i sukoba unutar crnogorske političke zajednice od početka XX vijeka, koji su se reflektovali i na pitanje identiteta, Pavlović dolazi do vrlo važnih zaključaka. Naime, ključna linija podjele bila je vezana za interpretaciju odnosa između Srba i Crnogoraca. U zavisnosti od toga da li su zauzimali stav da su Crnogorci i Srbi istog etničkog porijekla ili da je Crnogorski identitet poseban u etničkom smislu, politički akteri imali su i različit odnos prema identitetu političke zajednice. Pavlović naglašava: „Ova suprotstavljena gledišta i pretpostavka etničke i nacionalne ,jednakosti“ između Crnogoraca i Srba pokazali su se kao krucijalni razlog konflikta između suprotstavljenih ideologija u Ujedinjenom Kraljevstvu Srba, Hrvata i Slovenaca, kao i u SFRJ, stvorenoj krajem II Svjetskog rata“" (Pavlović, 2003: 90). Svako insistiranje na potpunoj čistoti, autentičnosti i homogenosti crnogorskog identiteta u njegovom trajanju i zanemarivanje činjenice da je u pitanju dinamičan fenomen, vodilo bi u isključivi etnonacionalizam. Takođe, jačanjem građanske komponente, u praksi a ne samo normativno, izbjegavamo aktiviranje autoritarnih potencijala nacionalnog (tzv. tribalnog, etničkog nacionalizma) izrazito kolektivističke i ekskluzivističke crte. ${ }^{7}$

Na drugoj strani, u samom crnogorskom okruženju postoje države čije je ustavno uređenje bliže konsocijacijskoj demokratiji nego građanskom

\footnotetext{
O nacionalnom identitetu Crnogoraca između ranog XIX vijeka i prve polovine XX vijeka u smislu postojanja osobenog nacionalnog karaktera koji su opisivali etnografi, istraživači i putopisci iz različitih zemalja, vidjeti u: Čagorović i Carmichael, 2006: 61-68.

7 Veličanje sopstvene i unižavanje drugih nacija, govor mržnje, potenciranje razlike u odnosu na drugog, uz nerijetko prisutne teorije zavjere, sužavanje identiteta pojedinca na kulturno-etničku komponentu nacionalnog i neafirmacija pluraliteta identiteta, primat kolektivnog nad individualnim, neke su od karakteristika etničkog nacionalizma u kojem preovladavaju autoritarni potencijali (Marković, 2010: 54).
} 
društvu. U nizu susjednih država koje su prije etnonacionalno nego građanski definisane, svakako je ilustrativan primjer Bosne i Hercegovine, čije su etničke specifičnosti, kao i događaji iz posljednje decenije prethodnog vijeka, uslovili potrebu da se, kao nosioci suvereniteta, ustavno definišu prvenstveno etno-nacionalni kolektiviteti, a tek posredno pojedinci/građani. Pritom, političke i socio-ekonomske tenzije, kojima je prožeta poslijeratna svakodnevica te države, upućuju na zaključak da je, u situaciji kada se jednom da primat grupno diferenciranim u odnosu na individualna prava, teško naći funkcionalni balans između ova dva nivoa zaštite prava. Posljedično je, kako u odnosu na bosanski slučaj konstatuje Haverić „vlada sastavljena od triju etničkih stranaka pozdravljena kao izraz suverenosti triju naroda“ što u konačnom značajno odudara od bilo kakvog građanskog definisanja države i nacije (Haverić, 2006: 101).

\section{REFERENDUM O NEZAVISNOSTI REPUBLIKE CRNE GORE I DEBATE O USTAVU}

Imajući u vidu činjenicu da je crnogorsko društvo izrazito etnički pluralno i politički veoma heterogeno, kao i da je aktuelni politički momenat, dijelom, određen turbulentnim događajima iz posljednje decenije prošlog vijeka i njihovim skorijim posljedicama, ne čudi da je proces zaokruživanja nacionalnog identiteta Crne Gore praćen polemikama, neslaganjima, pa i nesporazumima. Ovo je postalo posebno uočljivo tokom pregovora o sadržaju Ustava Crne Gore, koji su pratili obnovu nezavisnosti i koji su, pokazaće se, u bitnom, postavili okvir za izgradnju crnogorskog društva kao dominantno građanskog. ${ }^{8}$

Pregovori o sadržaju novog Ustava Crne Gore pokazali su očekivanu podijeljenost parlamentarnih stranaka i drugih političkih i društvenih aktera, povodom odredbi koje se odnose na uređenje države i državni identitet. ${ }^{9}$ Žestoke polemike, koje su tom prilikom vođene, zahvatile su sva pitanja

8 Građani Crne Gore su, na referendumu održanom 21. maja 2006. godine, izglasali obnovu crnogorske nezavisnosti. Nakon referenduma su uslijedili parlamentarni izbori, a potom i dug proces usaglašavanja stavova parlamentarnih stranaka povodom sadržaja budućeg Ustava Crne Gore.

9 Nakon nekoliko rundi pregovora i brojnih ukrštanja stavova, Ustav Crne Gore je 19. oktobra 2007. godine usvojen u Skupštini. Tom prilikom je za Prijedlog Ustava glasalo 55 od ukupno 81 poslanika. Dvotrećinsku većinu, neophodnu za usvajanje Ustava, obezbijedile su, osim vladajuće koalicije Demokratske partije socijalista, Socijaldemokratske partije i Hrvatske građanske inicijative i tri tada opozicione parlamentarne stranke: Pokret za promjene, Liberalna partija i Bošnjačka stranka. Protiv Prijedloga Ustava su, tom prilikom, bili poslanici Srpske liste, Socijalističke narodne partije, Narodne stranke i Demokratske srpske stranke. Tri poslanika albanskih nacionalnih partija nisu prisustvovala glasanju. 
koja su u javnosti bila prepoznata kao „identitetska”. Polemisano je, kako oko krucijalnog pitanja, odnosno pitanja ustrojstva države (država konstitutivnih naroda/država građana), tako i oko niza izvedenih pitanja, vezanih za službeni jezik i državne simbole (himna, zastava, grb).

Prilikom pregovora o Ustavu, manifestovana je duboka politička podijeljenost, inače karakteristična za crnogorsku političku scenu. Kao što je to, prethodno, bio slučaj i prilikom priprema za referendum o državnopravnom statusu Crne Gore, koji je doveo do grupisanja brojnih političkih stranaka u dva velika bloka, tako su i pregovori o Ustavu donijeli novo privremeno sažimanje crnogorske političke scene. Ovo je za posljedicu, ponovo, imalo blokovsku podijeljenost političke javnosti, koja je, donekle, bila katalizirana činjenicom da je referendumska homogenizacija, još uvijek, bila svježa. ${ }^{10}$ Iako je na prvi pogled, moglo izgledati da su blokovi u ustavnim debatama bili identični onim predreferendumskim, pažljivija analiza bi pokazala da su, u postreferendumskom periodu, neke političke stranke imale drugačije stavove o navedenim pitanjima nego što je to bio slučaj sa njihovim predreferendumskim političkim saveznicima. ${ }^{11}$ Ova činjenica, dijelom, ilustruje dinamiku procesa oblikovanja crnogorskog državnog identiteta: ako je značajno pitanje nezavisnosti privremeno homogenizovalo političke stranke i fragmentiranu crnogorsku političku scenu grupisalo u dva velika bloka, ubrzo se pokazalo da u etnički heterogenom društvu, kakvo je crnogorsko, različite stranke imaju i različite vizije izgradnje državnog identiteta Crne Gore. U prilog navedenom zaključku govori činjenica da su, ubrzo nakon referenduma, u spomenutim predreferendumskim blokovima počeli da se javljaju disonantni tonovi povodom budućeg državnog ustrojstva. ${ }^{12}$

Imajući u vidu značaj zatvaranja „identitetskih" tema, i to kako za same žitelje Crne Gore tako i za stabilnost Crne Gore kao etnički pluralne za-

10 U susret referendumu, oformljen je Pokret za nezavisnost Crne Gore, kao i Pokret za očuvanje zajednice sa Srbijom. Gotovo sve političke stranke u Crnoj Gori su, do referenduma, uzele učešće u jednom od ova dva pokreta.

11 Primjera radi, Socijalistička narodna partija i partije članice Srpske liste su, u predreferendumskom pozicioniranju, bile u bloku koji se zalagao za opstanak zajednice sa Srbijom, da bi, u kasnijim pregovorima o Ustavu, ove političke organizacije, dijelom, imale suprotstavljena gledišta. Socijalistička narodna partija se $\mathrm{u}$ tom periodu, naime, zalagala za građansku državu, dok je Srpska lista predlagala uređenje Crne Gore kao „države crnogorskog i srpskog naroda". Na drugoj strani, stranke koje su predstavljale okosni$\mathrm{cu}$ predreferendumskog Pokreta za nezavisnost su, tokom kasnijih pregovora o Ustavu, zagovarale građansko uređenje države, dok je njihov predreferendumski saveznik, Bošnjačka stranka, predlagala uređenje Crne Gore kao „države crnogorskog, srpskog i bošnjačkog naroda".

12 Podsjetićemo na upravo navedene primjere neslaganja između predreferendumskih partija saveznica, a povodom pitanja bitnih za državno ustrojstvo. 
jednice, a istovremeno uvažavajući činjenicu da političke stranke, u velikoj mjeri, oblikuju nacionalnu politiku (uključujući i „identitetsku”), u dijelu članka koji slijedi ćemo prikazati pozicije i perspektive crnogorskih parlamentarnih stranaka, koje su one zauzele u procesu izgradnje građanskog nacionalnog identiteta. Prije nego što pređemo na ovaj dio, podsjetićemo ukratko na nekoliko činjenica bitnih za zaključak koji će na kraju biti prezentovan, a koji se odnose na aktuelni politički momenat u Crnoj Gori, kao i na period u kome je izglasan Ustav:

1. Dvotrećinska većina kojom je usvojen aktuelni crnogorski Ustav je obezbijeđena nakon dugih pregovora, pri čemu je saglasnost partija manjinskih naroda, bez čije neophodne dvotrećinske većine, u datoj političkoj konstelaciji, vjerovatno ne bi bilo, dobijena tek na kraju i uz izvjesne ustupke;

2. Poslanici opozicionih partija su, bilo da se o radi građanskim ili nacionalnim partijama, bili protiv usvajanja ustavnog teksta (s izuzetkom Pokreta za promjene);

3. Neke partije koje, danas, učestvuju u vlasti a u trenutku donošenja Ustava su bile opozicione, u svojim programskim smjernicama ističu nepodobnost aktuelnih državnih simbola i potrebu da se isti izmijene;

4. Proces izgradnje nacionalnog (državnog) identiteta je otvoren proces u kome su, kako je pokazalo crnogorsko političko iskustvo, mogući izvjesni kompromisi ali je veoma teško obezbijediti punu saglasnost svih političkih aktera.

Pošto je, kako smo naglasili, izgradnja građanskog nacionalnog identiteta - proces, koji je, u slučaju Crne Gore, počeo proklamacijom novog "građanskog" Ustava i nastavio da se odvija u periodu koji je uslijedio, postavlja se pitanje kako politički akteri percipiraju dinamiku i tok ovog procesa. Stoga ćemo, u dijelu koji slijedi, prezentovati percepcije i aktuelne pozicije crnogorskih parlamentarnih stranaka u odnosu na navedenu temu. Ovaj prikaz će nam omogućiti uvid u dinamiku izgradnje proklamovanog građanskog identiteta Crne Gore, kao i mogućnost da sagledamo očekivanja različitih političkih subjekata kada je ovaj proces u pitanju, odnosno da ukažemo na moguće prepreke na tom putu. 


\section{CRNA GORA I PROBLEM KONSOLIDACIJE DEMOKRATSKE POLITIČKE KULTURE}

Iako je temeljnim odredbama Ustava Crna Gora definisana kao "građanska država"13, u ustavnom tekstu postoje elementi koji uvažavaju činjenicu da je crnogorsko nacionalno biće etnički heterogeno ${ }^{14} \mathrm{i}$ kojima je, shodno tome, podržano nastojanje pripadnika manjinskih etničkih zajednica da autentično artikulišu vlastite interese i sopstvenu poziciju u društvu i državi. ${ }^{15}$ Po kombinaciji poštovanja individualnih prava i uvažavanja specifičnosti kolektiviteta i njihove potrebe da budu autentično predstavljeni, Crna Gora svakako nije izuzetak. Ranije je istaknuto da je, danas, teško identifikovati državu čije je ustrojstvo striktno "građansko", bilo u

13 U preambuli Ustava stoji da je jedna od polaznih tačaka donošenja Ustava bila i „odlučnost da smo, kao slobodni i ravnopravni građani, pripadnici naroda i nacionalnih manjina koji žive u Crnoj Gori: Crnogorci, Srbi, Bošnjaci, Albanci, Muslimani, Hrvati i drugi, privrženi demokratskoj i građanskoj Crnoj Gori“. Ovakvom proklamacijom je jasno istaknuto da je Crna Gora, sa ustavno-pravne strane, projektovana prvenstveno, kao građanska država ali je, istovremeno, uvažena činjenica da njeno nacionalno biće sačinjavaju pripadnici različitih naroda. Takođe, Članom 2 Ustava je istaknuto da je nosilac suverenosti u Crnoj Gori „građanin koji ima crnogorsko državljanstvo“ čime je, suštinski, Crna Gora utemeljena kao "građanska“ država. Ipak, čitavo peto poglavlje posvećeno je „posebnim manjinskim pravima“ koja se jemče manjinskim etničkim zajednicama, uz opasku da pripadnici manjinskih naroda i drugih manjinskih nacionalnih zajednica mogu koristiti ova prava „pojedinačno i u zajednici sa drugima“. Smatramo da način na koji su formulisane ove odredbe akcentuje građanski koncept države ali i uvažava potrebu da se manjinskim narodima jemče korektivne mjere koje bi trebalo da im omoguće očuvanje kulture, političku participaciju i, posljedično, punu integraciju u crnogorsko društvo, bez rizika od asimilacije. U najširem značenju, moguće je izdvojiti sljedeća obilježja građanske države: „Garantovan i zaštićen civilizacijski korpus ljudskih prava i sloboda, vladavina prava, slobodni izbori, kontrolisana i smjenjiva vlast, nezavisno sudstvo, razvijena lokalna samouprava, politički pluralizam, otklon prakse da oligarhijske strukture daju ton vlasti, garantovana i zaštićena svojina“ (Šuković, 2009: 184). Ustav Crne Gore: http://www. skupstina.me/images/dokumenti/ustav-crne-gore.pdf (01. 10. 2014.).

14 Posljednji popis stanovništa, koji je obavljen tokom aprila 2011. godine, potvrdio je etničku heterogenost stanovništva Crne Gore. Prilikom ovog popisa se, kada su u pitanju etničke kategorije koje prepoznaje navedeni dio ustavne preambule, $45 \%$ crnogorskih žitelja etnički samoidentifikovalo kao Crnogorci, 28,7\% njih se samoidentifikovalo kao Srbi, 8,6\% kao Bošnjaci, 4,9\% kao Albanci, 3,3\% kao Muslimani (u nacionalnom smislu) i oko 1\% kao Hrvati. Popis stanovništva, domaćinstava i stanova u Crnoj Gori 2011. godine, Zavod za statistiku Crne Gore, Saopštenje br. 83, Podgorica, od 12. 07. 2011. godine, str. 6-9. Unos na: http://www.monstat.org/userfiles/file/popis2011/saopstenje/saopstenje\%281\%29.pdf (12. 06. 2014.).

15 Odredbe koje se odnose na set manjinskih prava, a koje su sadržane u petom poglavlju Ustava (vidjeti fusnotu 13), uvrštene su u ustavni tekst na insistiranje nacionalnih stranaka manjinskih zajednica i to kao uslov da poslanici ovih stranaka u Parlamentu podrže Ustav. Identična je situacija bila i sa preambulom, koja je takođe spomenuta u fusnoti 13, pri čemu su, slično, narodi i nacionalne zajednice pojedinačno navedene na inicijativu stranaka manjinskih nacionalnih zajednica. 
smislu ustavno-pravne organizacije ili identitetskih elemenata. U praksi se, najčešće, radi o mješovitim modelima, koji uvažavaju etničke specifičnosti odnosne države ali i daju primat individualnim pravima u odnosu na kolektivna. Stoga smo mišljenja da je termine "građansko" i „etno-nacionalno" ispravnije postaviti kao dva čista ali apstraktna modela, između kojih se prostire dimenzija konkretnih i mješovitih identitetskih rješenja, nego sagledavati ove kategorije kao međusobno u potpunosti opozitne. Ukoliko se proces izgradnje građanskog nacionalnog identiteta u Crnoj Gori sagleda na taj način, postaje jasno da konstrukti „građanskog" $i$ „,nacionalnog” postaju otvoreni za različite interpretacije, pri čemu je, u uslovima objektivnog postojanja mješovitog modela, ${ }^{16}$ teško izdvojiti jedan kriterijum razlikovanja građanskog od etno-nacionalnog, koji bi nam dao za pravo da ga, u nastojanju da razlučimo građanske od etno-nacionalnih elemenata državne konstitucije, dosljedno primijenimo na sve aspekte identitetske problematike. Ovo, svakako, ostavlja mogućnost političkim akterima da i sami, zavisno od vlastite percepcije i interesa, intrpretiraju termine "građansko" i „nacionalno". Za crnogorsko društvo se, kao i za većinu postkomunističkih društava Balkana, može reći da je demokratsko po formi ali u velikoj mjeri, još uvijek autoritarno po intenciji. Zagorka Golubović u svom tekstu „Stranputice demokratizacije u postsocijalizmu“, skreće pažnju na nekoliko važnih momenata kada se razmatra pitanje prirode političkog identiteta postsocijalističkih društava Balkana, a koji su, rekli bismo, vrlo aktuelni i u sadašnjem trenutku. Najprije, izražena afektivna težnja za nacionalnim identitetom još uvijek kao da ima primat u odnosu na projekat demokratizacije društva u čijoj srži je uspostavljanje vladavine zakona i demokratske države, koja bi bila „otpornija“ na zloupotrebu u političke svrhe od strane političkih elita (Golubović, 2007: 368). Građanski, liberalno-demokratski nacionalni identitet neodvojiv je od građanskog političkog identiteta na nivou pojedinačnih pripadnika društva.

Pitanje demokratske konsolidacije suštinsko je pitanje transformacije bivših socijalističkih društava. Teoretičari transformacije poput Klausa Ofea i Wofganga Merkela, ističu specifičnosti ovog procesa u Istočnoj Evropi. Naime, procesi transformacije u zemljama bivšeg socijalizma teku na neko-

16 Ovdje mislimo na rješenja navedena u prethodnim referencama, kojima je, kako smo već naglasili, Crna Gora utemeljena kao građanska država uz izvjesne korektivne mehanizme, namijenjene zaštiti kulture i interesa manjinskih nacionalnih zajednica. Kao što naglašava Milan Podunavac, „potvrđuje se da u svim onim zajednicama u kojima postoji potencijalni „sukob lojalnosti“ (pretpolitičke i političke), a takve su gotovo sve moderne političke zajednice, „manjinsko pitanje“ valja nužno ugraditi u samo srce supstantivnog (osnovnog) konsenzusa te zajednice“ (Podunavac, 2001:197). 
liko nivoa istovremeno, što bitno otežava proces demokratizacije. Zemljama Zapadne Evrope za iste procese trebalo je nekoliko vjekova, dok se $\mathrm{u}$ slučaju postkomunističkih društava promjene dešavaju u veoma kratkom periodu i simultano. Osim toga, transformacijski procesi u ovim društvima prvenstveno su "politički projekat", koncipirani i sprovođeni dominantno od strane političkih elita (Merkel, 2011: 307). Merkel izdvaja četiri nivoa na kojima se proces konsolidacije i demokratizacije ostvaruje. ${ }^{17}$ Prvi imenuje kao ustavnu konsolidaciju (constitutional consolidation), drugi kao reprezentativnu konsolidaciju (representative consolidation), zatim slijedi konsolidacija ponašanja aktera veta (behavioral consolidation) i na kraju demokratska konsolidacija političke kulture (democratic consolidation of the political culture) (Merkel, 2008: 14). Za demokratsku konsolidaciju na prvom nivou potrebno je najmanje dok je za konsolidaciju političke kulture potrebno najviše vremena. Za našu temu je zanimljiva Merkelova upotreba Bertelsmanovog indeksa transformacije (Bertelsmann Transformation Index - BTI) iz 2005. godine. Podaci su prikupljani u periodu od dvije godine u 119 zemalja. $\mathrm{Na}$ skali od 1 do 10 države su, najprije, rangirane prema stepenu konstitucionalne konsolidacije i to na osnovu tri ključna kriterijuma: kriterijum institucionalnog djelovanja (institutional efficiency), institucionalne transparentnosti (institutional transparency) i institucionalne inkluzivnosti (institutional inclusion ${ }^{18}$ Komparacijom zemalja u pogledu ostvarenog stepena konsolidacije na prvom nivou, Crna Gora ${ }^{19}$ je, zajedno sa Makedonijom, Ukrajinom i Bosnom i Hercegovinom uvrštena u grupu zemalja kod kojih postoje očigledni i značajni nedostaci u procesu konsolidacije na institucionalnom nivou. ${ }^{20}$

17 Merkel polazi od razlikovanja „negativne” i „pozitivne” konsolidacije koje je napravio Geoffrey Pridham. Prihvata koncept „pozitivne konsolidacije” koji podrazumijeva ne samo prihvatanje legitimnosti sistema i nepostojanje alternative od strane političkih elita, već i uključuje i obrasce stavova, vrijednosti i ponašanja na nivou pojedinačnih aktera. Ovako shvaćena konsolidacija demokratije zahtijeva relativno dug vremenski period, za razliku od koncepta „negativne” konsolidacije koji se fokusira na političke elite i u kom je taj vremenski period znatno kraći.

18 Prvi kriterijum odnosi se na kapacitet najvažnijih institucija da efikasno donose odgovarajuće političke odluke i obezbijede političku stabilnost. Drugi kriterijum podrazumijeva demokratsku legitimnost političkih odluka koje donose nadležni organi dok se treći kriterijum vezuje za neophodnost obezbjeđivanja političke i društvene integracije i participacije od strane ključnih institucija (Merkel, 2008: 16).

19 Tada u sastavu države Srbija i Crna Gora.

20 Što se tiče drugog nivoa konsolidacije, istraživanje je pokazalo Crna Gora spada u grupu zemalja u kojima se reprezentacija interesa ne može ocijeniti kao konsolidovana. Osim Srbije i Crne Gore, u ovu grupu spadaju i Ukrajina, Letonija, Makedonija i Bosna i Hercegovina. U pogledu stepena konsolidacije u okviru trećeg kriterijuma koji se odnosi na opasnost od antidemokratskog djelovanja „neformalnih“, politički relevantnih aktera, Crna Gora i Srbija nalaze se u grupi sa Bosnom i Hercegovinom i Albanijom. Za ove 
Podaci o stepenu konsolidacije na, za nas najzanimljivijem, četvrtom nivou političke kulture, pokazuju da su Srbija i Crna Gora rangirane između zemalja čija je demokratska politička kultura označena kao nerazvijena (Letonija, Bugarska, Ukrajina, Rumunija) i onih čija je politička kultura označena kao poluautoritarna (Rusija, Moldavija i Bosna i Hercegovina) (Merkel, 2008: 17). Na osnovu stepena konsolidacije ostvarenog na sva četiri nivoa, Srbija i Crna Gora kategorisane su kao nekonsolidovane izborne demokratije (unconsolidated electoral democracies), zajedno sa Makedonijom, Albanijom, Ukrajinom i Bosnom i Hercegovinom (Merkel, 2008: 20). Institucionalna tranzicija neodvojiva je od vrjednosne a njihova neusklađenost je jedan od ključnih problema u izgradnji proklamovanog političkog identiteta Crne Gore. Preciznije rečeno, postoji značajno nepoklapanje institucionalnog ustrojstva države i temeljnih vrijednosnih orijentacija njenih građana, na šta ukazuje Olivera Komar. Ona političku kulturu u Crnoj Gori karakteriše kao podaničko-participativnu i upravo identifikuje nepodudaranje između liberalno-demokratske političke strukture i dominantno podaničke političke kulture (Komar, 2013: 130). Građanski, nacionalno-državni politički identitet svoju stabilnost mora utemeljiti na stabilnosti liberalno-demokratskih institucija, pristupu političkim dobrima na racionalnoj i pravednoj osnovi, i posebno na vrijednosnoj komponenti građanskog društva. Dakle, od procesa demokratizacije društva u svim njegovim aspektima, a posebno od napredovanja u prihvatanju liberalno-demokratskih vrijednosti, zavisiće stabilizacija i učvršćivanje zajedničkog političkog identiteta. Razvoj demokratskog građanstva oličenog u vrijednostima individualizma, neautoritarnosti, racionalnosti i participationosti, te shodno tome, transformacija dominantno podaničke političke kulture u participativnu, nameću se kao ključni zadaci crnogorskog društva i neophodni uslovi za dugoročnu stabilnost političkog identiteta. ${ }^{21}$

zemlje karakteristično je postojanje potencijala za usporavanje procesa demokratizacije koji je prvenstveno vezan za problem organizovanog kriminala i njegovu povezanost sa određenim političkim strukturama (Merkel, 2008: 17).

${ }^{21}$ Važan preduslov konsolidacije svakog građanskog identiteta jeste odgovarajući proces političke socijalizacije i u njemu posebno prepoznata uloga sistema obrazovanja. Crna Gora je započela proces reformi obrazovnog sistema i jedna od najvažnijih promjena vezana je za uvođenje predmeta Građansko vaspitanje (obavezni predmet u VI i VII razredu Osnovne škole) i Građansko obrazovanje (izborni predmet za četiri razreda Gimnazije). Prepoznajući značaj građanskog vaspitanja i obrazovanja za razvoj demokratske političke kulture u Crnoj Gori, Vlada Crne Gore usvojila je Strategiju građanskog vaspitanja i građanskog obrazovanja za period od 2007 - 2010. Kroz nastavu građanskog vaspitanja/ obrazovanja afirmišu se vrijednosti očuvanja etnokulturnog pluralizma, dijaloga, tolerancije i saradnje kao i potreba jačanja zajedničkog građanskog političkog identiteta Crne Gore (Kašćelan, 2010: 442). 
Imajući u vidu ovakvo stanje, u nastavku ćemo opisati pozicije koje parlamentarne stranke u Crnoj Gori zauzimaju prema izgradnji Ustavom proklamovanog, građanskog nacionalnog identiteta. Budući da, kako smo upravo naznačili, termin "građansko" može biti višeznačan, u počeku ćemo, zavisno od odgovora koje smo dobili tokom intervjuisanja, prikazati šta ovaj termin, posmatrano iz perspektive različitih političkih stranaka, znači. Nakon pitanja koje se odnosi na pojašnjenje pojma "građansko", lista pitanja koju smo koristili kao okosnicu za razgovor sa ispitanicima je obuhvatala i ostale identitetske teme, kao što su: primjenjivost građanskog državnog uređenja na crnogorske prilike, državni simboli, kolektivna prava etničkih zajednica, aktivnosti političkih partija u pravcu izgradnje građanskog nacionalnog identiteta i percepcija prepreka koje stoje na tom putu. Takođe, nakon prikaza pozicija crnogorskih parlamentarnih stranaka, pružićemo normativni osvrt na ove pozicije i stavove, u odnosu na značenja pojma "građanski nacionalni identitet" koja smo prikazali u uvodnom dijelu rada.

\section{ODREĐENJA PARLAMENTARNIH STRANAKA U IZGRADNJI GRAĐANSKOG NACIONALNOG IDENTITETA}

U ovom dijelu članka prikazuju se pozicije i perspektive crnogorskih parlamentarnih stranaka, koje su one zauzele u procesu izgradnje građanskog nacionalnog identiteta. Osim prikupljanja zvaničnih partijskih saopštenja, materijal koji se odnosi na predmet analize smo obezbijedili serijom intervjua sa funkcionerima parlamentarnih političkih stranaka. Intervju je bio polustrukturiran i inicijalno je sadržao niz pitanja koja referiraju na definiciju građanske države, državne simbole, kolektivna prava etničkih zajednica i aktivnosti odnosne partije povodom identitetskog oblikovanja države. U ovom dijelu istraživanja, intervjuisali smo predstavnike Demokratske partije socijalista (DPS), Socijaldemokratske partije (SDP), Socijalističke narodne partije (SNP), Demokratskog fronta (DF), Pozitivne Crne Gore (PCG) i Bošnjačke stranke (BS).

Tokom pregovora o Ustavu, postalo je jasno da predstavnici političkih stranaka termine "građansko" i "nacionalno" koriste tako da se pitanja koja su ovim problemima obuhvaćena mogu svesti na dvije komplementarne problemske ose. $^{22}$

22 Očekivano je da su, $\mathrm{u}$ interpretaciji političkih subjekata, pitanja iz obje ose podjednako „opterećena” građanskim, odnosno nacionalnim. Pregovori o Ustavu su, naime, pokazali da su oni politički akteri koji su se zalagali za „čistiju” građansku varijantu u identitetskoj ravni, zagovarali sličan stav i u ustavno-pravnoj osi. Istovremeno, stranke koje su naginjale mješovitom ili etno-nacionalnom modelu su, takođe, na identičan način pristupale 
Te ose bismo mogli označiti kao: ${ }^{23}$

1. Ustavno-pravnu, koja se odnosi na pitanje nosioca suvereniteta $\mathrm{u}$ državi (pojedinac ili kolektiviteti), odnosno individualnih i kolektivnih prava;

2. Identitetsku, koja se odnosi na pitanja državnih simbola (himne, zastave, grba) i službenog jezika.

U nastavku ćemo, polazeći od ove dvije ose koje su identifikovane kao problemske, prezentovati segmente Ustava Crne Gore koji se na njih odnose, a koji svakako jesu bili predmet polemike u periodu koji je prethodio usvajanju Ustava. Da bismo, konačno, prezentovali percepcije parlamentarnih stranaka kada su ovi problemi u pitanju, ispod ustavnih odredbi ćemo prikazati i segmente sprovedenih intervjua, koji se odnose na interpretacije i inicijative političkih stranaka povodom ovih problema.

\section{Građansko određenje države: ustavno-pravna problematika}

Ustavne odredbe koje ćemo izdvojiti kao krucijalne u određenju Crne Gore kao „građanske države" su sljedeće: ${ }^{24}$

pitanjima koja se odnose na obje ose. Primjera radi, DPS, SDP i SNP, stranke koje slove za građanske, su tokom pregovora uglavnom zastupale stav da nije neophodno da prava manjinskih zajednica budu navedena u Ustavu, tako da je lista ovih prava našla mjesto u najvišem pravnom aktu tek nakon intervencija manjinskih nacionalnih partija. Istovremeno, "građanske” stranke su insistirale na identitetskim rješenjima i rješenjima iz oblasti državnih simbola koja su, prema njima, ,utemeljena u tradiciji Crne Gore” i „prihvatljiva za sve građane" iako nije postojao konsenzus o sadržaju tih simbola a, pokazalo se, ni o njihovoj sveprihvaćenosti. Takođe, „nacionalne” stranke, poput Srpske narodne stranke i Bošnjačke stranke, su u odnosu na obje ose imale stavove koji su više na fonu etnonacionalnog. Tako je Srpska narodna stranka predlagala da se dosljedno razradi ustav koji bi počivao na etno-nacionalnom suvrenitetu crnogorskog i srpskog naroda uz zaštitu kolektivnih prava manjina, dok su za državnu zastavu predlagali modifikovanu srpsku nacionalnu zastavu a za službeni jezik srpski. Bošnjačka stranka je, u početku pregovora, insistirala na tripartitnom etničkom uređenju države koje bi obuhvatilo Crnogorce, Srbe i Bošnjake kao konstitutivne elemente. Ista stranka je, u ovom periodu, predlagala da državna zastava bude formirana tako što će svaki narod u nju unijeti „nešto svoje” dok bi službeni jezici trebalo da budu crnogorski, srpski i bosanski.

${ }^{23}$ Uvid da su (u interpretaciji predstavnika političkih stranaka) termini „građansko“ i „nacionalno" problemski vezani za dvije prezentovane ose pomogao nam je i u operacionalizaciji pojma "građansko" odnosno formulisanja pitanja koja smo uvrstili u intervju, a koja se odnose na ovaj pojam.

24 Odredbe iz preambule koje se odnose na dihotomiju građansko/nacionalno smo ranije komentarisali pa ćemo ih, da se ne bismo ponavljali, ovdje izostaviti. Podsjetićemo, ukratko, na već navedeni zaključak da je ovaj dio preambula koncipiran tako da je jasno naglašen primat individualnih, građanskih prava ali su i navedeni narodi koji sačinjavaju nacionalno i društveno biće Crne Gore, s naglaskom na tome da Crnu Goru konstituišu 
- Crna Gora je građanska, demokratska, ekološka i država socijalne pravde, zasnovana na vladavini prava (Član 1);

- Nosilac suverenosti je građanin koji ima crnogorsko državljanstvo. Građanin vlast ostvaruje neposredno i preko slobodno izabranih predstavnika (Član 2).

Iako je Ustavom Crne Gore građanin (odnosno - pojedinac) određen za nosica suvereniteta, $\mathrm{u}$ tekstu su, kako je ranije naglašeno, našle mjesto i odredbe koje se odnose na prava etničkih zajednica, odnosno njihovih pripadnika. ${ }^{25}$ Ta prava su najvećim dijelom sadržana u posebnom (petom) poglavlju Ustava. Ovdje ćemo navesti ona manjinska prava koja imaju pravnopolitičku pozadinu, odnosno ona koja se odnose na prvu problemsku osu:

- Pravo na autentičnu zastupljenost u Skupštini Crne Gore i skupštinama jedinicama lokalne samouprave $\mathrm{u}$ kojima čine značajan dio stanovništva, shodno principu afirmativne akcije (Član 79, tačka 9);

- Pravo na srazmjernu zastupljenost u javnim službama, organima drŽavne vlasti i lokalne samouprave (Član 79, tačka 10);

- Pravo na osnivanje savjeta za zaštitu i unapređenje posebnih prava (Član 79, tačka 13). ${ }^{26}$

Sa normationog aspekta, naglasićemo da se na pitanje: da li se na ovaj način uobličen korpus manjinskih prava (koji podrazumijeva ustavno prepoznavanje grupno diferenciranih prava manjinskih etničih zajednica) kosi sa građanskim modelom države - ne može dati jednoznačan odgovor. Naime, kako je istaknuto u uvodnom dijelu rada, u praksi ne postoje čisti oblici građanskih država, koji bi bili u potpunosti lišeni bilo kakvih referenci na etničke elemente ili na grupno diferencirane oblike zaštite etničkih kolektiviteta, bilo u identitestskoj sferi, bilo u oblasti ustavno-pravne regulative. Stoga je, u normativnoj analizi ovog segmenta određenja crnogorske države,

pripadnici ovih naroda a ne kolektiviteti.

25 U prvom dijelu Člana 49, koji pripada navedenom petom poglavlju, stoji da se ,pripadnicima manjinskih naroda i drugih manjinskih nacionalnih zajednica jemče prava i slobode koje mogu koristiti pojedinačno i u zajednici sa drugima". Tako je i ovom prilikom naglašeno da pojedinac ima primat u odnosu na zajednicu, odnosno da udruživanje i predstavljanje na nivou etnosa nikoga od pripadnika manjinskih naroda ne obavezuje.

26 Iako su nacionalni savjeti zamišljeni kao krovne institucije manjinskih naroda, koje bi trebalo da ulogu posrednika između manjinskih naroda i države realizuju kroz partnerski odnos u, prije svega, kulturološkoj ravni, njima je ostavljena i mogućnost da prate dinamiku realizacije posebnih manjinskih prava i da u tom procesu učestvuju davanjem sugestija i primjedbi. 
problemu najprikladnije pristupiti komparativno, smještajući ga u kontekst društava koja su oblikovana sličnim političkim i socio-ekonomskim procesima kao i crnogorsko. U tom smislu, smatramo da su modeli ustavnog određenja Bosne i Hercegovine i Srbije najprikladini za komparaciju, budući da se i u ovim slučajevima radi o društvima koja su etnički pluralna i koja su bitno oblikovana disolucijom nekadašnje SFRJ. Podsjetićemo da Ustav Bosne i Hercegovine, ${ }^{27}$ kao i Ustav Srbije, ${ }^{28}$ odnosno Hrvatske, ${ }^{29}$ sadrži eksplicitne elemente ekskluziviteta pojedinih etničkih zajednica, dok se pripadnici svih etničkih zajednica koje nisu ustavno prepoznate tretiraju kao građani. U ovom segmentu, crnogorsko rješenje jeste bliže građanskom polu dimenzije građansko/etničko nego što je to sa ustavnim dokumentima koje smo odredili kao komparativne jedinice, budući da je, u preambuli teksta ${ }^{30}$ Ustava Crne Gore, jasno data prednost građanskom elementu identiteta $\mathrm{u}$ odnosu na etnički. Takođe, Ustav Srbije, kao i onaj crnogorski, tretira prava

27 Ovo je posebno izraženo u Ustavu Bosne i Hercegovine, koji prepoznaje Bošnjake, Hrvate i Srbe kao „konstitutivne narode” i u kome su pojedina politička prava pojedinca omeđena njegovom etničkom pripadnišću. Ovakva ustavna rješenja dovela su do paradoksalne situacije da se građani Bosne i Hercegovine koji nisu pripadnici konstitutivnih naroda suočavaju sa problemima u ostvarivanju nekih građanskih i političkih prava, što se, opet, kosi sa ustavnom odredbom o zabrani diskriminacije. Čitava situacija je eskalirala i dobila sudski epilog kroz slučaj „Sejdić - Finci”, na koji upućujemo čitaoca. Ustav BiH, unos: http://www.ads.gov.ba/v2/attachments/1951_USTAV_BOSNE_I_HERCEGOVINE_bos. pdf (01. 20. 2014.).

28 U preambuli Ustava Srbije stoji da se Ustav donosi polazeći od „državne tradicije srpskog naroda i ravnopravnosti svih građana i etničkih zajednica u Srbiji.“ Iako se ovom formulacijom uvažava etnička pluralnost srpskog društva, kao i potreba za ravnopravnošću etničkih zajednica, istovremeno se naglašava i državotvorna uloga srpskog naroda. Predmet debata bio je i Član 13 Ustava Srbije, koji je naslovljen kao „Zaštita državljana i Srba u inostranstvu.“ Ovaj član sadrži odredbu prema kojoj „Republika Srbija razvija i unapređuje odnose Srba koji žive u inostranstvu sa matičnom državom." Ovako formulisana odredba otvara pitanje značenja termina "matične države“ što se, recipročno, odražava na status nacionalnih manjina u Srbiji.

29 U tekstu preambule Ustava Hrvatske, Hrvatska se određuje kao „nacionalna država hrvatskog naroda i država pripadnika nacionalnih manjina: Srba, Čeha, Slovaka, Talijana, Mađara, Židova, Nijemaca, Austrijanaca, Ukrajinaca, Rusina, Bošnjaka, Slovenaca, Crnogoraca, Makedonaca, Rusa, Bugara, Poljaka, Roma, Rumunja, Turaka, Vlaha, Albanaca i drugih, koji su njezini državljani, kojima se jamči ravnopravnost s građanima hrvatske narodnosti i ostvarivanje nacionalnih prava u skladu s demokratskim normama OUN-a i zemalja slobodnoga svijeta." Prava nacionalnih manjina su sadržana u četiri stava Člana 15. Unos na: http://www.zakon.hr/z/94/Ustav-Republike-Hrvatske (16. 09. 2014.).

30 Još jednom ćemo podsjetiti da u preambuli Ustava Crne Gore stoji da je Ustav donešen polazeći (i) od „odlučnosti da smo, kao slobodni i ravnopravni građani, pripadnici naroda i nacionalnih manjina koji žive u Crnoj Gori: Crnogorci, Srbi, Bošnjaci, Albanci, Muslimani, Hrvati i drugi, privrženi demokratskoj i građanskoj Crnoj Gori." Istovremeno, u Članu 12 stoji da Crna Gora štiti „prava i interese crnogorskih državljana” što više odgovara građanskoj definiciji nacije, nego što je slučaj sa Ustavom Srbije, u kome je, analognim članom, prednost data etničkom principu. 
manjina (u segmentu „Ljudska i manjinska prava i slobode”), dok je Ustav Bosne i Hercegovine posebno dosljedan u razrađivanju prava konstitutivnih naroda ove države, kao što je, istovremeno, veoma restriktivan prema onim građanima koji nisu pripadnici ovih naroda. Dio teksta Ustava Crne Gore koji se odnosi na manjinska prava može se, u svijetlu ovih činjenica, kao i činjenice da je u preambuli crnogorskog Ustava jasno data prednost građanskoj komponenti u odnosu na etničku, prije tretirati kao korektivni mehanizam koji služi postizanju pune participacije pripadnika manjinskih naroda u društvenim i političkim procesima Crne Gore, nego kao instrument političke separacije manjinskih etničkih zajednica.

U nastavku ćemo prezentovati djelove komentara naših ispitanika koji se odnose na upravo navedenu problematiku, a na kraju ćemo dati vlastiti osvrt, u nastojanju da povežemo odgovore ispitanika sa temom našeg rada.

Miodrag Vuković (DPS) smatra da činjenica da je Crna Gora definisana kao građanska država, zapravo, temeljna činjenica ustavne organizacije Crne Gore. Po njemu to znači, da je „,temelj države pojedinac” bez obzira na "nacionalne, vjerske i druge razlike koje mogu postojati među ljudima", te da Crna Gora „ima većinski narod, a to je njen politički narod, odnosno svi njeni građani”. Po pitanju primjenjivosti i održivosti građanskog ustavnog rješenja u Crnoj Gori, predstavnik DPS-a navodi da je građanski koncept „politički spas” za Crnu Goru kao društvenu zajednicu koji preventira u perspektivi moguću destabilizaciju, naglašavajući i da je ovakvo uređenje „u skladu sa tendencijama koje postoje u savremenom svijetu”. ${ }^{31}$ Smatrajući da je građanski okvir najpodesniji za afirmaciju svih različitosti jednog društva, Vuković smatra da se u konceptu narodne suverenosti suspenduju individualna prava pojedinaca koji ne pripadaju konstitutivnim grupama. Usljed potrebe da se, na neki način, omogući politička participacija i društvena integracija kolektiviteta koji participiraju u društvenom biću Crne Gore, u Ustav je uvršteno poglavlje o posebnim, manjinskim pravima, definisano onako kako to predviđaju međunarodni standardi. ${ }^{32} \mathrm{U}$ ovoj partiji navedeno rješenje u Ustavu percipiraju kao svojevrsnu „kohabitaciju nacionalnog i građanskog". Pri tom, odredbe o afirmativnoj akciji ${ }^{33}$ koje su sadržane u Ustavu Crne Gore i koje se odnose na reprezentovanje manjin-

31 Naš ispitanik prepoznaje i činjenicu da, u stvarnosti, nema „,dovršenih“ građanskih država već se više radi o „procesima“ koji, u perspektivi, treba da dovedu do formiranja idealne građanske države.

32 Riječ je o petom poglavlju Ustava koje razmatra „posebna - manjinska prava“ a o kome je već bilo riječi.

33 Za raspravu o primjeni afirmativne akcije u građanskim društvima, vidi: Young, 2005: 233-273. 
skih naroda ",ne bi smjele da budu trajne, već bi trebalo da traju onoliko koliko traje rizik od asimilacije manjinskih zajednica". ${ }^{34}$ Zanimljivo je da predstavnik DPS-a, kao ideal „građanskog društva” navodi Francusku „u kojoj su svi Francuzi” i skandivanske zemlje u kojima „ne postoje nacionalne, već samo jezičke razlike". ${ }^{35}$ Glavnu smetnju u uspostavljanju građanskog koncepta države, Vuković vidi u okruženju, iz koga, kako kaže, povremeno stižu „loše poruke“ prema Crnoj Gori, što, po njegovom mišljenju, remeti proces izgradnje istinski građanske države. On dalje smatra da je problem u tome što veliki broj građana same Crne Gore nije dosegao svijest o značaju „lošeg izbora“. ${ }^{36}$ Vuković u rezimeu naglašava da ovaj proces remete „unutrašnji ekstremi kao i pritisci sa strane“ a izvjestan udio, kako kaže, imaju i globalna kretanja.

Portparol Socijaldemokratske partije (SDP) Mirko Stanić takođe naglašava da ustavne odredbe o građanskoj državi znače da je nosilac suvereniteta građanin ",bez obzira na nacionalnu ili neku drugu specifičnost". Navodeći da je SDP politička organizacija koja je, tokom devedesetih godina prošlog vijeka u svojim redovima imala veliki broj pripadnika manjinskih naroda, Stanić dalje navodi i da se njegova partija svakako zalaže za puno poštovanje manjinskih prava, "čak i preko mjere međunarodno propisanog, ako to odgovara građanski našim prilikama i potrebama". Analizirajući primjenjivost građanskog koncepta na crnogorske uslove, Stanić naglašava da je stav njegove stranke da je građansko uređenje države u Crnoj Gori i moguće ${ }^{37}$ i poželjno ${ }^{38}$. Pojašnjavajući ovaj stav, on navodi

34 Ovakav stav Vuković temelji na preporukama iz Lunda, koje, kako ističe, kažu da je afirmativna akcija opravdana u građanskim društvima u onim oblastima gdje postoji očigledan pritisak u pravcu asimilacije manjinskih zajednica. Afirmativna akcija, Vuković navodi, ovdje nije trajno rješenje, već politička korekcija koja treba da osigura trajanje osobenosti manjinskih zajednica koja je koriste i njeno dejstvo prestaje onda kada se ukloni pritisak na manjinsku zajednicu i postigne njena integracija u društvo.

35 Ova analogija je diskutabilna zbog različitih istorijskih i političkih tokova koji su uslovili multietničnost balkanskih država i država poređenja.

36 Vuković pojašnjava da misli na činjenicu da su izborne konvencije i pobjede o pojedinim crnogorskim opštinama proslavljene uglavnom uz zastave „stranih država“.

37 Na ovom mjestu, Stanić podsjeća da se SDP beskompromisno zalaže za građansko uređenje države i da njegova stranka nikako neće prihvatiti bilo kakva rješenja o predstavljanju koja bi Crnu Goru transformisala u državu naroda, kao što su dvodomni parlament, rotirajući predsjednici i slično.

38 Stanić podsjeća na činjenicu da u Crnoj Gori postoji veliki broj etničkih zajednica, uključujući i romsku, koje nisu našle mjesto u crnogorskom Ustavu i elaborira stav da je građansko uređenje države neophodno i zbog društvene prohodnosti pripadnika ovih zajednica. Naime, u slučaju da je Crna Gora definisana kao država konstitutivnih naroda sa primatom kolektivnih prava u odnosu na građanska, pripadnici ovih zajednica bi u praksi bili diskriminisani, kao što je slučaj sa onim građanima Bosna i Hercegovine koji ne pripadaju 
da put ka formiranju stabilne države koju bi pripadnici različitih naroda „doživljavali kao svoju” vodi preko daljeg jačanja građanskog identiteta i zalaganja za multikulturalizam. U ovom kontekstu je zanimljivo da i predstavnik ove partije, kao značajnu prepreku ka uspostavljanju građanskog društva, vidi činjenicu da ne postoji spremnost „predstavnika nekih zajednica" da se priznaju rezultati referenduma o državno-pravnom statusu. On, naime, navodi da je „stvaranje građanske države posljedica referenduma” te da se „moraju uvažiti rezultati referenduma da bi se dalje išlo ka građanskoj državi" ${ }^{39}$

Poziciju Socijalističke narodne partije (SNP) koja se tiče izgradnje Crne Gore kao građanske države nam je, pojasnio direktor ove stranke Vladimir Vujović. Vujović je, osvrćući se na činjenicu da je SNP u dijelu javnosti percipiran kao „prosrpska” stranka u kojoj postoji „,animozitet prema manjinama", naveo da je ova stranka nedavno osvojila odbornička mjesta u onim opštinama u kojima žive isključivo pripadnici manjinskih naroda. ${ }^{40}$ SNP je, prema riječima našeg sagovornika, stranka koja „preferira građansku opciju" i koja je, nakon usvajanja Ustava, sačinila alternativni ustavni tekst pod naslovom „Ustav kakav je trebao Crnoj Gori” koji je, kako Vujović kaže „pomiriteljski". On, međutim, zapaža da je teško povući oštru razliku između "nacionalnog" i „građanskog" pa čak i između individualnih i kolektivnih prava, uvažavajući tako činjenicu da u praksi rijetko postoje čisti primjeri građanske ili nacionalne države. On ističe da je stav SNP-a da je građanski model nacionalnog identiteta ne samo poželjan, nego i jedini moguć u Crnoj Gori ali naglašava i da je nužno poštovati sva manjinska prava. Poštovanje kolektivnih prava manjina je, prema našem sagovorniku, značajno i zbog toga što pripadnici manjina moraju imati „čvrstu vjeru da je sistem uredio njihova prava na adekvatan način". Prepreke u zaokruživanju građanskog identiteta Crne Gore Vujović vidi u politici vlasti, odnosno u činjenici da kod vlasti ne postoji volja za demokratskim iskorakom koji bi pospiješio ovaj proces.

Funkcionerka Demokratskog fronta (DF) i poslanica ove koalicije u Skupštini Crne Gore, Branka Bošnjak, prezentovala je stav svog poslaničkog kluba polazeći od inerpretacije termina "građansko". Prema njenim riječima, ovaj termin odnosi se na državno uređenje u kome se prioritet

„konstitutivnim narodima“.

39 Ovakvo rezonovanje je teško do kraja dosljedno primijeniti, o čemu je bilo riječi ranije.

40 SNP je na nedavno održanim opštinskim izborima u Petnjici, mjestu u kome žive isključivo Bošnjaci i Muslimani, osvojila jedan odbornički mandat. Jednog odbornika ova stranka ima i u Gradskoj opštini Tuzi, čiji su žitelji dominantno Albanci. 
daje građaninu/pojedinacu a ne nacionalnostima. Za našu temu je značajno da Bošnjak naglašava da Crna Gora $u$ praksi ne funkcioniše dosljedno kao građanska država ${ }^{41}$ kao i da određene stranke naglašavaju razlike $\mathrm{i}$ „vladaju zahvaljujući podjelama”. ${ }^{42}$ Ona je, kao problematično, izdvojila i pitanje određenja manjinskih zajednica, odnosno onih etničkih zajednica koje bi mogle da uživaju ona prava koja su Ustavu označena kao manjinska. ${ }^{43}$ Bošnjak navodi da u njenoj koaliciji smatraju da bi trebalo precizno odrediti one zajednice koje bi mogle da koriste posebna - manjinska prava u Crnoj Gori, odnosno zajednice koje bi se smatrale manjinskim. Ipak, smatra i da je teško identifikovati postojan kriterijum koji bi dao za pravo da se neke zajednice odrede kao manjinske, za razliku od drugih. ${ }^{44}$ Kao prepreku u zaokruživanju građanskog nacionalnog identiteta, Bošnjak ističe „interese nekih partija” ${ }^{45}$ kao i to da je napredak u ovom procesu, prije svega, stvar političke volje. Navodi i da vlast vlada na podjelama, te da njoj, zapravo, nije u interesu redukovanje kriterijuma nacionalnog kao u politici djelatnog. Govoreći o poželjnosti i mogućnosti da se u Crnoj Gori izgradi građanski nacionalni identitet, još jedna prepreka koju identifikuje naša sagovornica, je neadekvatnost obrazovnog sistema i medijskih sadržaja, koji, kako kaže, ne promovišu dovoljno potrebu očuvanja identitetske posebnosti pojedinačnih etnokulturnih zajednica.

Stav Pozitivne Crne Gore (PCG), prema riječima poslanika ove stranke Dritana Abazovića, jeste da je građanski oblik državnog uređenja „najbolji oblik koji poznaje ustavno pravo". Određujući pojam "građansko" naš sagovornik ističe da se ovaj termin odnosi na one države koje podjednako tretiraju sve pojedince i narode koji u njima žive, bez obzira na moguće specifičnosti. On konstatuje da je čista građanska država samo ideal koji

${ }^{41}$ Bošnjak argumentuje ovaj stav između ostalog i time „što u Crnoj Gori postoje nacionalne partije“. Prema mišljenju poslanice Demokratskog fronta, i neki zakoni „demantuju građansko ustrojstvo države“. Ovdje Bošnjak navodi primjer afirmativne akcije, koja, prema njenom mišljenju, nije u skladu sa građanskim konceptom.

42 Bošnjak ovdje misli, prije svega, na partije koje su u vlasti na državnom nivou.

43 Ovdje je, kao ilustrativna, istaknuta debata koja je među pripadnicima srpske zajednice u Crnoj Gori vođena povodom njihovog statusa. Naime, shodno ranije navedenom dijelu Ustava koji dozvoljava formiranje manjinskih nacionalnih savjeta, i pripadnici srpske zajednice u Crnoj Gori su, svojevremeno, formirali takav savjet. Ovaj potez je naišao na oštre kritike velikog dijela političkih predstavnika srpske nacionalne zajednice, praćen prigovorom da Srbi u Crnoj Gori nisu manjina (već konstitutivni narod) te da, stoga, ne mogu imati (manjinski) nacionalni savjet.

44 Ističući da se radi o ličnom stavu, Bošnjak navodi da je ovdje krucijalno pitanje maternjeg jezika, iz čega slijedi da bi samo albanska i romska zajednica mogle da koriste manjinska prava.

45 Ovdje se, takođe, misli na vladajuće stranke. 
je u praksi teško postići, ali da treba raditi na tome da se svi identiteti koji sačinjavaju odnosno državu osjete uključenim i dobrodošlim. PCG, prema riječima Abazovića, podržava punu implementaciju kolektivnih prava manjinskih nacionalnih zajednica, a partijski stav je da su produbljivanje podjela po etničkim šavovima i diskriminacija dva momenta koja značajnu usporavaju proces izgradnje građanskog nacionalnog identiteta u Crnoj Gori.

$\mathrm{Na}$ kraju, prezentovaćemo i perspektivu jedne nacionalne političke organizcije - Bošnjačke stranke (BS), koja već godinama participira u vlasti. ${ }^{46}$ Stavove ove stranke nam je prenio Suljo Mustafić, funkcioner BS i aktuelni potpredsjednik Skupštine Crne Gore. Govoreći o značenju termima "građansko" i o državi kao „zajednici građana“ Mustafić je naveo da ne postoji čisto građanski individualni identitet koji isključuje etničku pripadnost, odnosno da su "građani“ koji čine populaciju države istovremeno i pripadnici nekog od naroda ${ }^{47}$ Mustafić kaže da je mišljenje BS da se građanskom pripadnošću (u političkoj ravni) ne isključuje nacionalni osjećaj (u etničkoj ravni). Govoreći o mogućnosti izgradnje građanskog nacionalnog identiteta u Crnoj Gori, Mustafić navodi činjenicu da su Sjedinjene Američke Države, kao oblik državne organizacije koji je, možda, najbliži onom idealnom tipu građanskog, nastale na potpuno drugačiji način nego što je to slučaj sa balkanskim državama, da predstavljaju, u kulturološkom smislu „melting pot“ i da taj koncept nije do kraja primjenjiv u balkanskim uslovima. Zbog ovih razlika, nametanje crnogorskog identiteta „svima građanima Crne Gore“ prema američkom modelu, a u našim uslovima, prema Mustafićevim riječima, za BS znači - asimilaciju. ${ }^{48}$ Mustafić navodi da je, u sadašnjim uslovima, teško zamisliti ovakav identitet koji ne bi podrazumijevao asimilaciju manjina, ali ostavlja mogućnost da se, kada bude postignuta puna integracija pripadnika manjinskih naroda u društvo i kada država iskorijeni diskriminaciju po etničkoj osnovi, spontano desi etabli-

46 Među nacionalnim strankama manjinskih naroda, odabrali smo Bošnjačku stranku, zbog nekih specifičnosti. Naime, tokom više puta pominjanih pregovora o sadržaju Ustava, čelnici ove stranke (tada još uvijek opozicione) su inicijalno predlagali da Crna Gora bude uređena kao država naroda, da bi kasnije podržali "građanski“ Ustav uz obavezu da se u njemu nađe set manjinskih prava. Takođe, BS je jedina nacionalna stranka nekog manjinskog naroda u Crnoj Gori čiji su čelnici više puta isticali potrebu za korekcijom državnih simbola.

47 Ovo mišljenje, indirektno, povezuje problematiku građanskog društva sa pitanjem nadnacionalnog državnog identiteta, kakav je, primjera radi, dijelom postojao u SFRJ. Za više, vidjeti: Sekulić, 2004: 175-200.

48 Stav BS je, kako kaže Mustafić, da crnogorski identitet treba da baštine oni koji su nacionalni Crnogorci, dok pripadnici ostalih etničkih zajednica treba da njeguju svoje nacionalne osobenosti, što, kako naš sagovornik ističe, ne dovodi u pitanje pripadnost Crnoj Gori kao političkoj zajednici. 
ranje građanskog nacionalnog identiteta, bez rizika od asimilacije manjina. Govoreći o kolektivnim pravima, Mustafić navodi da BS apsolutno podržava ovaj oblik zaštite manjinskih naroda, naglašavajući da ova prava treba da doprinesu opstanku kulturalnih speficičnosti manjinskih naroda. On naglašava i da BS posmatra kolektivna prava kao komplementarna individualnim/građanskim pravima. Zalažući se za puno poštovanje prava $\mathrm{u}$ obje ravni. Kao glavne prepreke $\mathrm{u}$ procesu izgradnje građanskog nacionalnog identiteta, Mustafić naglašava diskriminaciju, etničku distancu i nepoštovanje normi o srazmjernoj zastupljenosti u državnim organima.

Prethodnom sistematizacijom obuhvatili smo pozicije parlamentarnih stranaka u Crnoj Gori koje su značajne za temu istraživanja. Rezimirajući ono što je prezentovano, izložićemo nekoliko zaključaka koji se odnose na prvu problemsku osu, a koji će nam olakšati formulisanje konačnog zaključka u završnim razmatranjima:

- Konstituisanje Crne Gore kao u perspektivi građanske države, sa primatom individualnih prava građana $\mathrm{u}$ odnosu na kolektivna prava etničkih zajednica, nije sporno i to kako ni za građanske, tako ni za nacionalne stranke manjinskih naroda. Ovo nam daje za pravo da zaključimo da je ideja o Crnoj Gori kao građanskoj državi etablirana među političkim strankama u Crnoj Gori, te da je perspektiva Crne Gore kao prevashodno građanske države zajednička vodilja različitih političkih grupacija u Crnoj Gori;

- Za političke partije u Crnoj Gori nisu sporne ustavne odredbe o kolektivnim pravima (manjinskih) etničkih zajednica i svi politički subjekti insistiraju na poštovanju ovih prava. Međutim, postoje izvjesne dileme koje se odnose na neke aspekte kolektivnih prava, kao što je način njihove implementacije i način konkretizovanja ovih ustavnih obaveza zakonskim aktima;

- Političke partije na različitim mjestima identifikuju probleme u konkretizaciji ustavnih normi o građanskoj državi. Stranke koje participiraju u vlasti sklone su da ove probleme interpretriraju u kontekstu političkog ambijenta u kome se Crna Gora nalazi, dok opozicione stranke ukazuju na to da su neophodne promjene na nivou državne vlasti da bi proces izgradnje Crne Gore kao istinski građanske države bio dovršen;

- Nacionalne partije manjinskih naroda čvršće od građanskih stranaka zagovaraju stav da je zaštita kolektivnih prava etničkih zajednica neophodna i da ona mora biti dugoročna; 
- Sa normativnog aspekta, u referentnoj grupi država u kojima djeluju socio-politički impulsi slični onima koji su djelatni u Crnoj Gori, može se konstatovati da Crna Gora jeste ostvarila ustavno određenje koje je bliže građansko-političkom nego etno-političkom polu. U toj vizuri, set manjinskih prava, koji je sadržan u Ustavu, komplementaran je temeljnom građanskom određenju države i olakšava participaciju pripadnika manjinskih naroda $\mathrm{u}$ građanskom društvu. Smatramo da je ovakvo balansiranje građanskog i etničkog poseban kvalitet crnogorskog političkog ambijenta ali i crnogorskog društva, koji je, očigledno, kao takav prepoznat i od strane predstavnika političkih stranaka u Crnoj Gori, što nedvosmisleno proizilazi iz konstatacija koje su navedene u prethodnom dijelu teksta.

\section{Identitetska ravan: državni simboli}

Ustavne odredbe koje se odnose na državne simbole sadržane su u Članu 4 najvišeg pravnog akta. ${ }^{49}$ Po pitanju potrebe da se Crna Gora ustavno definiše kao građanska država, nađen je kompromis koji je izbalansirao građanska i kolektivna prava i tako omogućio da Ustav bude usvojen glasovima kako građanskih, tako i stranaka manjinskih naroda, pitanje državnih simbola u Crnoj Gori, ako je suditi po izjavama većeg dijela naših sagovornika, ostaje otvoreno. Odnosno, problemi koje smo svrstali u simboličkoidentitetsku osu ne dozvoljavaju da se identifikuje jednoznačni kriterijum na osnovu kojeg bi se mogli odrediti stavovi parlamentarnih političkih stranaka u Crnoj Gori, zavisno od njihovog statusa ili programskih smjernica: niti su stranke koje konstituišu vladajuću koaliciju sasvim jedinstvene po ovom pitanju, niti su građanske (kao ni nacionalne) stranke saglasne o tome kako državni simboli Crne Gore treba da izgledaju.

Kada je u pitanju identitetska problemska osa, naši sagovornici iz Demokratske partije socijalista i Socijaldemokratske partije bili su saglasni $u$ tome da su aktuelni državni simboli, uključujući zastavu, grb i himnu - odgovarajući i da ih, bar za sada, ne treba mijenjati. Miodrag Vuković (DPS) smatra da će građani Crne Gore, vremenom, ostvariti puniju identifikaciju sa simbolima koji, za sada, izazivaju sporenja. Vuković ovaj stav, dijelom, temelji i na mišljenju da je za stabilnost države, kao i za punu identifikaciju građana sa njenim simbolima, nužno ispoštovati vrijeme koje je potrebno

49 Crna Gora ima grb, zastavu i himnu; Grb Crne Gore je zlatni dvoglavi orao sa lavom na prsima; Zastava Crne Gore je crvene boje sa grbom na sredini i zlatnim obrubom; Himna Crne Gore je „Oj svijetla majska zoro“ (Ustav Crne Gore, Član 4). 
da se ostvari ova identifikacija. I naš sagovornik iz SDP-a smatra da su simboli više puta potvrđeni i to kako među građanima Crne Gore ${ }^{50}$ tako i u parlamentu i da, za sada, nema potrebe za bilo kakvim promjenama. Zanimljiv je stav SDP-a po kome su aktuelni simboli izraz volje "građanske Crne Gore" i da bi bilo kakav kompromis po pitanju državnih simbola doveo do urušavanja procesa izgradnje građanskog nacionalnog identiteta.

Na drugoj strani, nalaze se predstavnici opozicionih stranaka koje smo intervjuisali i koji, mada i sami zagovaraju građansko ustrojstvo države, smatraju da aktuelni simboli nisu odgovarajući, da oni "dijele Crnu Goru“ i da bi put ka izgradnji građanskog nacionalnog identiteta vodio preko korekcije ovih simbola. Tako je naš sagovornik iz SNP-a prenio stavove svoje stranke, koji se odnose na zastavu i himnu, a koji podrazumijevaju potrebu za izvjesnim korekcijama u ravni simbola. Po pitanju zastave, naime, SNP predlaže da se, uz aktuelnu državnu zastavu, pravno verifikuje i postojanje „narodne“ zastave, koja je, dijelom, već prihvaćena među crnogorskim građanima i to uglavnom kod onog dijela crnogorske populacije koji se na referendumu opredijelio za opstanak zajednice sa Srbijom..$^{51}$ Sličan je stav Demokratskog fronta koji, prema riječima Branke Bošnjak, insistira na tome da "podjele budu prevaziđene“ i putem postizanja „konsenzusa o pitanju simbola“. ${ }^{52}$ Poslanicima DF-a je, prema riječima naše sagovornice, bliska ideja o uvođenju „narodne zastave“ koju je inicirao SNP. ${ }^{33}$ Naša sagovornica smatra da je i prilikom izglasavanja nacionalnih simbola u Skupštini previđena volja velikog dijela poslanika i građana Crne Gore, te da bi se ovakva situacija, koja ide na ruku vlasti, mogla lako prevazići kompromisom, ukoliko bi za tim postojala politička volja. Pozicija Pozitivne Crne Gore je, prema riječima našeg sagovornika iz ove partije, takođe na fonu upravo prezentovanih stavova građanskih opozicionih stranaka. PCG, naime, poštuje aktuelne državne simbole ali je partijski stav da, ako postoji potreba da se o ovom pitanju razgovara, svakako treba naći rješenje koje bi bilo prihvatljivo za što veći broj građana Crne Gore. Abazović ističe i da je

50 Stanić pojašnjava da misli na činjenicu da je crnogorska nezavisnost obnovljena pod „sadašnjim simbolima” kao i na to da su sadašnji simboli izraz volje parlamentarne većine, koja je jasno manifestovana kada je Ustav usvajan.

${ }^{51}$ Zastava koju SNP predlaže za narodnu, odnosno „trobojka“ ima utemeljenje i u tradiciji Crne Gore.

52 Bošnjak podsjeća da su aktuelni simboli usvojeni tokom perioda rada Skupštine koji je protekao u znaku bojkota zasijedanja od strane opozicije, tako da se opozicioni poslanici u Parlamentu, tada, uopšte nisu izjašnjavali po pitanju simbola. Naša ispitanica navodi da je ovo loša praksa koja je ostavila prostor za podjele po ovom pitanju.

53 Bošnjak ovdje naglašava da bi, ukoliko dođe do korekcija nacionalnih simbola, trebalo obratiti pažnju i na zahtjeve predstavnika nacionalnih stranaka manjinskih naroda. 
pitanje postizanja kompromisa ili konsenzusa o državnim simbolima stvar političke volje ali i problem koji bi, ako bi bio riješen na adekvatan način, mogao da stabilizuje građanski nacionalni identitet Crne Gore.

Na kraju ćemo prezentovati i stav Bošnjačke stranke po pitanju državnih simbola. Iako već godinama participira u vlasti na državnom nivou, zajedno sa strankama koje aktuelne državne simbole smatraju odgovarajućim, stav Bošnjačke stranke, prema riječima našeg sagovornika iz ove političke organizacije, jeste da bi državne simbole trebalo korigovati „tako da odgovaraju multietničkom nacionalnom i državotvornom biću Crne Gore“. Naime, prema mišljenju čelnika BS, izgled državnih simbola jeste veoma važan za izgradnju građanskog nacionalnog identiteta Crne Gore, a da bi se omogućila identifikacija pripadnika manjinskih naroda sa ovim simbolima je, kako kaže Mustafić, bitno da pripadnici manjinskih zajednica u samim simbolima ne budu diskriminisani.

Već smo istakli da različite političke stranke, mada programski građanske, imaju i različite stavove o državnim simbolima Crne Gore, što je upravo navedenim primjerima ilustrovano. Očigledno je da programska dihotomija građansko/nacionalno ne igra značajnu ulogu u određenju stranačke pozicije po ovom pitanju. Jedina pravilnost na koju bismo, možda, mogli ukazati je ta da građanske stranke koje su konstituenti vlasti ${ }^{54}$ ne gledaju blagonaklono na potrebu dijela parlamentarnih stranaka da se ponovo otvori pitanje državnih simbola, dok su opozicione stranke, mahom, nezadovoljne aktuelnim rješenjima.

Po pitanju normativnog osvrta na simboličku osu, naglasićemo da je, na temelju definicija građanskog političkog identiteta koje smo predložili na početku članka, teže izvući dosljedne zaključke u ravni simboličke problematike, nego u oblasti ustavno-pravnih rješenja. Ovo dolazi otud što je, $\mathrm{u}$ balkanskim okolnostima, teško zamisliti državne simbole koji bi bili posve čisti od svih mogućih primjesa etničkog supstrata. To je, svakako, slučaj i sa državnim simbolima Crne Gore. Primjera radi, državna zastava, kao i nacionalni grb Crne Gore, u krajnjem, referiraju na medijevalni period postojanja države (odnosno - njene prethodnice Zete) i kao takvi su neraskidivo vezani za crnogorski narod, čiji je garant postojanja upravo - država Crna Gora, kao što je, sa druge strane, postojanje Crne Gore, barem u pojedinim periodima, u bitnom zavisilo od političke organizacije crnogorskog etnosa. Ovo je, svakako, prepoznato i kroz sentiment etničkih Crnogoraca među crnogorskim indipendistima, koji je, kada su u pitanju aktuelni državni simboli, uglavnom pozitivan (što se vidi i iz navedenih izjava predstavnika

${ }^{54}$ Mislimo, prije svega, na DPS i SDP. 
političkih stranaka). Sličan odnos bezuslovne međuzavisnosti simboličkog i etničkog nalazimo, svakako, i kod ostalih naroda koji konstituišu nacionalno biće Crne Gore (Bošnjaci - zastava sa ljiljanima; Albanci - zastava sa dvoglavim orlom itd.) Iz ove nemogućnosti da se iz državnih simbola, u našim uslovima, u potpunosti apstrahuju etnički elementi, proizilazi i činjenica da je teško normativno i dosljedno zauzeti jedan ugao gledanja koji bi, objektivno, konvergirao jednoj od definicija građanskog političkog identiteta koje smo predložili na početku teksta. Cijenimo, stoga, da je normativnom dijelu problematike najuputnije pristupiti iz pozicije subjektivnog - gdje bismo kao različite uglove gledanja na simboličku problematiku tretirali naracije predstavnika političkih organizacija u Crnoj Gori, cijeneći da je podesno ono rješenje koje je prihvatljivo za što veći broj aktera, odnosno ona solucija koja konvergira konsenzusu. Međutim, ovo pitanje do te mjere polarizuje političke stranke u Crnoj Gori da je teško ukazati na jedno rješenje koje bi zadovoljilo čak i ovako postavljeni kriterijum. Štaviše, rješenje koje bi bilo prihvatljivo za veći dio političkih organizacija podrazumijevalo bi ne samo korekcije sadržaja postojećih simbola, već i standardizovanje nove forme ovih simbola.

\section{ZAKLJUČNA RAZMATRANJA}

Imajući u vidu značaj procesa izgradnje građanskog političkog identiteta Crne Gore i ključnu ulogu koju u tom procesu imaju političke partije, na kraju ćemo navesti nekoliko najvažnijih zaključaka i ukazati na moguće pravce daljeg djelovanja. Mišljenja smo da je postojeće ustavno rješenje o utemeljenju Crne Gore kao građanske države dobar odgovor na potrebu jačanja zajedničkog političkog identiteta u uslovima izražene multikulturalnosti. Konsolidaciji zajedničkog građanskog političkog identiteta doprinosi i koncept diferenciranog građanstva, razrađen kroz garantovana posebna manjinska prava. Smatramo da je neophodno imati u vidu da izgradnja zajedničkog političkog identiteta u društvima izrazito multikulturalnog karaktera kakvo je crnogorsko, ne smije biti dominantno stvar političkog inženjeringa i oblikovanja „odozgo". Da bi bio dugoročno stabilan i prihvaćen politički identitet mora biti onaj koji dolazi „odozdo". Ukoliko bi bio kreiran isključivo od strane države, političke ili intelektualne elite, usljed nedostatka legitimiteta i emotivne ukorijenjenosti bio bi potreban „,nedopustivo visok stupanj moralnog i kulturnog inžinjerstva kako bi nadišao očekivani otpor" (Parekh, 2006: 58). Otvorenost za različite poglede na zajednički identitet i spremnost na kompromis oko problematičnih mo- 
menata, kao srž građanskog koncepta identiteta, neophodni su preduslovi za njegovu stabilnost. ${ }^{55}$

Primijenjeno na crnogorsko društvo, to bi značilo da se mora unapređivati ambijent koji pogoduje postizanju kompromisa, te da bi ovaj kompromis morao počivati na uvažavanju različitih pozicija političkih partija. Političke partije, naime, često zanemaruju da je suština koncepta građanske države i društva u spremnosti na kompromis i otvorenosti u rješavanju spornih pitanja. U tom smislu, posebno naglašavamo odgovornost političkih partija u ostvarivanju ovog Ustavom proklamovanog normativnog rješenja. Smatramo da doprinos političkih partija u procesu izgradnje građanskog identiteta može (i mora) biti mnogo veći. To se, u prvom redu, odnosi na političke partije koje vrše vlast i koje bi, s obzirom na mehanizme koje imaju na raspolaganju, mogle da učine mnogo više u konsolidaciji građanskog političkog identiteta.

U kontekstu ranije prezentovanih pozicija koje su političke partije $\mathrm{u}$ Crnoj Gori zauzele povodom identitetskih pitanja, očigledno je da postoji značajna (a za crnogorske prilike i uobičajena) „blokovska” podijeljenost koja, ukoliko u obzir uzmemo i perspektivu političkih organizacija manjinskih naroda, čak prelazi u fragmentaciju. Prezentovano istraživanje je, naime, pokazalo da političke partije u Crnoj Gori mahom deklarativno podržavaju građanski oblik državnog uređenja, kao i njemu odgovarajući primat individualnih $\mathrm{u}$ odnosu na grupno diferencirana prava, čime je ustavno-pravni dio identitetske problematike, $u$ najznačajnijim segmentima, zatvoren. Sa druge strane, istraživanjem je nedvosmisleno pokazano da ona pitanja koja se odnose na užu identitetsku oblast (poput pitanja nacionalnih/državnih simbola) nastavljaju da polarizuju crnogorsku političku scenu, sa slabim šansama da, u postojećem odnosu snaga i sa već čvrsto zauzetim pozicijama, $\mathrm{u}$ perspektivi bude postignut konsenzus. $\mathrm{U}$ tom smislu je evidentno da podjele među crnogorskom političkom elitom, koje su u predreferendumskom periodu bile naglašene i manifestovale se povodom državno-pravnog statusa, nastavljaju da perzistiraju i u postreferendumskoj Crnoj Gori, preslikavajući se na različite aspekte identitetskih pitanja. Imajući u vidu već konstatovanu podijeljenost crnogorske političke

55 U simboličkoj ravni prisutno je nezadovoljstvo postojećim rješenjima iako postoji određeni stepen inkluzivnosti. Što se tiče te dimenzije političkog identiteta, mogli bismo se složiti sa sljedećim stavom: „Nadnacionalni (tj. državni) simboli se u Crnoj Gori u određenoj mjeri povezuju sa jednim partikularnim identitetom - crnogorskim, ne samo od strane crnogorskih građana već i na političkoj sceni. Ovo u određenoj mjeri otežava razvoj osjećanja pripadnosti i ponosa u vezi sa jedinstvenim domovinskim identitetom" (Spaić, 2010: 58). 
scene, kao i činjenicu da simboličko-identitetska problemska osa koja dijeli političke aktere u crnogorskom društvu (uključujući i političke partije) ima istorijsku pozadinu koja se može pratiti kroz čitavi minuli vijek, u skorijoj budućnosti, u ovoj oblasti, ne treba očekivati veće promjene. Štaviše, uzimajući u obzir i to da političke partije ne samo da učestvuju u kreiranju državnog identiteta Crne Gore, nego u periodima kada je homogenizacija potencijalnih birača neophodna, rado i posežu za identitetskom problematikom i argumentacijom (nailazeći, obično, na plodno tle), ostaje otvoreno pitanje koliko uopšte kod kreatora politika ovih partija postoji spremnost da se rješavanju ovih problema pristupi iskreno, konstruktivno i odgovorno.

\section{LITERATURA}

Brubaker, R. (1996). Civic and Ethnic Nations in France and Germany, u: J. Hutchinson i A. Smith (ur.). Ethnicity. New York: Oxford University Press, 168-174.

Cerutti, F. (2006). Identitet i politika, u: F. Cerutti (ur.). Identitet i politika. Zagreb: Politička kultura, 23-62.

Čagorović, N. i Carmichael, C. (2006). Constructing and Rethinking Montenegrin National Identitety, Narodna umjetnost, 43 (1): 59-74.

Divjak, S. (2002). Nacija, kultura, građanstvo. Beograd: Službeni list SRJ.

Divjak, S. (2006). Problem identiteta, kulturno, etničko, nacionalno i individualno. Beograd: Službeni glasnik.

Golubović, Z. (1999). Ja i drugi: antropološka istraživanja individualnog i kolektivnog identiteta. Beograd: Republika.

Golubović, Z. (2007). Socijalizam i postsocijalistička društva. Beograd: Službeni glasnik.

Haverić, T. (2006). Ethnos i demokratija: slučaj Bosne i Hercegovine. Sarajevo: Rabic.

[Jenkins] Dženkins, R. (2001). Etnicitet u novom ključu. Beograd: Čigoja štampa.

Kašćelan, V. (2010). Obrazovanje za demokratsko građanstvo i razvoj demokratskih vrijednosti, u: P. Vukotić (ur.). Crna Gora u XXI stoljeću - u eri kompetitionosti: Obrazovanje. Podgorica: Crnogorska akademija nauka i umjetnosti, 427-444.

Kecmanović, D. (2006). Da li smo sišli s uma ili dokaži da si Srbin. O etnonacionalizmu i o nama. Novi Sad: Izdavačka knjižarnica Zorana Stojanovića.

[Kymlicka, W.] Kimlika, V. (2004). Multikulturalizam: multikulturno građanstvo. Podgorica: CID.

[Kymlicka, W.] Kimlika, V. (2009). Savremena politička filozofija. Beograd: Nova srpska politička misao.

Knežević, R. (2012). Politička kultura. Podgorica: CANU.

Komar, O. (2013). Birači u Crnoj Gori: faktori izborne i partijske preferencije. Beograd: Čigoja štampa. 
Kupchan, C. (1995). Nationalism and Nationalities in the New Europe. Ithaca: Cornell University Press.

Marković, M. (2010). Ogledi o nacionalnom i demokratskom pitanju: Postjugoslavenski slučaj Srbije. Beograd: Službeni glasnik.

Merkel, W. (2008). Plausible Theory, Unexpected Results: The Rapid Democratic Consolidation in Central and Eastern Europe, Internationale Politik und Gesellschaft/ International Politics and Society, (2): 11-29.

Merkel, W. (2011). Transformacija političkih sustava. Zagreb: Fakultet političkih znanosti Sveučilišta u Zagrebu.

Parekh, B. (2006). Nova politika identiteta. Zagreb: Politička kultura.

Pavlović, S. (2003). Who are Montenegrins? Statehood, identity and civic society, u: F. Bieber (ur.). Montenegro in Transition: Problems of Identity and Statehood. Baden-Baden: Nomos Verlagsgesellschaft, 83-106.

Podunavac, M. (2001). Princip građanstva i poredak politike. Beograd: Čigoja štampa.

Sekulić, D. (i Šporer, Ž., Hodson, R., Massey, G. i Županov, J.) (ur.) (2004). Sukob i tolerancija: O društvenoj uvjetovanosti nacionalizma i demokracija. Zagreb: Naklada Jesenski i Turk.

[Smith] Smit, A. (1998). Nacionalni identitet. Beograd: Čigoja štampa.

Spaić, B. (2010). Etika i građanin, u: M. Đurović (ur.). Crna Gora u XXI stoljeću - u eri kompetitivnosti: Pitanja vrijednosti. Podgorica: Crnogorska akademija nauka i umjetnosti, 37-61.

Šuković, M. (2009). Ustavno pravo: univerzalna ustavna tematika i Ustavno pravo Crne Gore. Podgorica: CID.

Vrcan, S. (2006). Nacija, nacionalizam i moderna država. Zagreb: Golden Marketing Tehnička knjiga.

Vujačić, I. (2012). Uvodnik: Protivrječja političkog identiteta, Godišnjak, 6 (8): 7-11.

Vuković-Ćalasan, D. (2013). Politički identitet u multikulturnim društvima sa osvrtom na Crnu Goru, Politički život, 9: 77-94.

Young, M. I. (2005). Pravednost i politika razlike. Zagreb: Naklada Jesenski i Turk. 


\title{
Izazovi izgradnje građanskog identiteta u Crnoj Gori: postreferendumske podjele i sporovi političkih stranaka
}

\section{Danijela Vuković-Ćalasan, Mehmed Đečević}

\begin{abstract}
SAŽETAK
Postkomunistička tranzicijska društva suočavaju se s potrebom oblikovanja novih političkih identiteta u procesu izgradnje države i nacije, i to u složenim unutrašnjim okolnostima. S obzirom na to da je proces izgradnje političkog identiteta nacionalnodržavne zajednice jedan od najznačajnijih za njezin opstanak i funkcioniranje, postavlja se pitanje kakva je oblika stvarni politički identitet postreferendumske Crne Gore, naročito u dihotomiji građansko/nacionalno. Na temelju jedne od definicija građanskoga političkog identiteta naglašava se ustavno određenje Crne Gore kao građanske države. Istovremeno, uvažavajući veliku važnost koju u procesu oblikovanja Crne Gore kao građanske nacionalne zajednice imaju političke stranke, sagledavaju se različite pozicije koje one zauzimaju u spomenutom procesu. Identitetske pozicije stranaka predstavljene su u odnosu na dvije problemske osi: ustavno-pravnu i identitetsku u užem smislu. Upozorava se da su u postreferendumskom razdoblju političke stranke u odnosu na identitetska pitanja grupirane gotovo identično kao što su u predreferendumskom razdoblju bile grupirane oko pitanja državnopravnog statusa te se u zaključku konstatira blokovska podijeljenost u Crnoj Gori u vezi s identitetskom problematikom, kao i male mogućnosti da se identitetske polemike uskoro riješe konsenzusom.
\end{abstract}

KLJUČNE RIJEČI: građanski identitet, Crna Gora, političke stranke, politički identitet 


\title{
Challenges of Civil Identity Construction in Montenegro: Post-referendum Polarisation and Debates between Political Parties
}

\author{
Danijela Vuković-Ćalasan, Mehmed Đečević
}

\begin{abstract}
SUMMARY
Post-communist transition societies are facing a need to create new political identities in the process of state and nation building in complex internal circumstances. Since the process of creating political identity of national-state society is one of the most significant for its survival and functioning, it raises the question: what is the nature of real political identity of the post-referendum Montenegro, especially the one grounded in the social/national dichotomy. One of the definitions of civil political identity emphasizes the constitutional Montenegro as the civil state. At the same time, respecting the great importance of political parties in the process of creation of Montenegro as a civil and national society, different positions which these parties expressed in the mentioned process have been observed. Identity positions of parties are presented in relation to two axes of the problem: the constitutional-legal and on identity in the narrower sense. It is pointed out that in relation to identity issues in the post-referendum period, political parties have been grouped almost identically as they were grouped in relation to the state-legal status in pre-referendum period. The authors concluded that there is a block division of identity questions in Montenegro as well as little chance for identity debates to be resolved by consensus in the near future.
\end{abstract}

KEY WORDS: civic identity, Montenegro, political parties, political identity 